\title{
Yalan Habere Karşı Tutum ve Davranışlar: Üç Üniversite Örneğinde Durum Araştırması
}

\author{
Attitudes and Behaviors About Fake News: A Case Study in Three Universities
}

\author{
Sibel Onursoy*, Erdem Alper Turan ${ }^{* *}$, Segâh Yeşilyurt*** ve Fatma Kübra Astam****
}

$\ddot{\boldsymbol{O}} \boldsymbol{z}$

Hukuki düzenlemelerin eksikliği ve uygulanma güçlüğü, kitlelerin kolayca yönlendirilebilmesini, kışkırtılabilmesini desteklemesi, sosyal medyanın önemli dezavantajları arasında yer almaktadır. Kullanıcılar, sosyal medya hesapları aracılı̆̆ıyla, ilk elden şahit oldukları haber değeri taşıyan olaylar hakkında bilgi, fotoğraf, video ve anlatım gönderebilme olanağına sahip olmuştur. Yalan/yanıltıcı bilgi ve içeriklerin hızlı bir biçimde yayılması sosyal ağları yalan haber barındırma açısından olumsuz bir üne kavuşturmuştur. Disiplinsiz gelişen haber/bilgi süreci doğal olarak farklı etkilere ve karmaşaya neden olabilmektedir. Bu nedenle, yalan haberlerin ya da bilgilerin kullanıcıya etkisi ve karar süreçlerinin değerlendirilmesi büyük önem taşımaktadır. Bu çalışmanın amacı yalan haberlere maruz kalabilen bireylerin, yalan haber değerlendirmesini açıklamak, yalan haberle başa çıkmada karar ve etki süreçleri, tutum ve davranışların belirlemektir. Bu araştırma nicel araştırma metodu kullanilan betimleyici bir alan araştırmasıdır. Veri toplama tekniği olarak anket tercih edilmiştir. Çalışma kapsamında Ankara, Samsun ve Eskişsehir'deki üç üniversitede ögrenim gören 230 öğrenciye gönüllülük esasıyla anket uygulanmıştır. Örneklem belirlemede olasılı̆̆a dayanan örnekleme yöntemi olan tabakalı örnekleme yöntemi kullanılmıştır. Yalan habere karşı tutum ve davranış örüntülerini ortaya çıkarmak için, üç üniversitenin örgün öğrenci evrenini temsil eden örneklemin yaş aralı̆̆l ve cinsiyet değişkenleri dikkate alınmıştır. Örgün ögrretim öğrencisi olmaları, dolayısıyla teknolojiye yakın, sosyal medya kullanıcısı ögrencilerin medya kullanımı, yalan haberle karşılaşma süreci, habere inanma/inanmama karar süreci, doğrulatma kategorilerinden oluşan anket uygulanmaktadır. Araştırma sonucunda bu örneklemin görsel nitelikli içerikleri daha inandırıcı bulduğu, propaganda ve yönlendirici özellikteki yalan haberlerin çoğunlukta olduğu ve magazin, siyaset, ekonomi haber türlerinde yaygın olduğu ortaya çıkmıştır.

\footnotetext{
* Doç. Dr., Anadolu Üniversitesi, Basın ve Yayın Bölümü, Eskişehir. E-posta: sonursoy@anadolu.edu.tr Assoc. Prof., Anadolu University, Journalism Department, Eskisehir/Turkey

** Öğretim Gör., Başkent Üniversitesi, İletişim Tasarımı Bölümü, Ankara. E-posta: erdemalperturan@ gmail.com Lecturer, Baskent University Communication Design Department, Ankara/Turkey

*** Öğretim Gör., Ondokuz Mayıs Üniversitesi, Çağrı Merkezi Hizmetleri Programı, Samsun. E-posta: segah.yesilyurt@omu.edu.tr

Lecturer, Ondokuz Mayis University, Call Center Services Program, Samsun/Turkey

**** Doktora Öğrencisi, Anadolu Üniversitesi, Sosyal Bilimler Enstitüsü, Basın ve Yayın Ana Bilim Dalı, Eskişehir. E-posta: fatmakubraastam@anadolu.edu.tr

PhD Student, Anadolu University, Social Sciences Institute, Press and Publication Department, Eskisehir/Turkey
}

Geliş Tarihi - Received: 27.06.2020

Kabul Tarihi - Accepted: 26.09.2020 
Anahtar Sözcükler: Sosyal medya; yalan haber; yalan haber etkisi; doğruluk kontrolü; kullanıcı tutum ve davranışlarl; kasıtlı ve kasıtsı yanlış bilgi; kusurlu bilgilendirme; bilgi kirliliği.

\section{Abstract}

Lack of legal regulations and difficulties in enforcement, supporting the easy manipulation and provocation of the masses are among the major disadvantages of social media. Users can the opportunity to send information, photos, videos and narratives about the news events that they witness firsthand through their social media accounts. The malicious use of private and corporate accounts, which had the opportunity to spread the fake information and content quickly, caused their social networks to have a negative reputation for hosting fake news. The news or information process that develops without discipline can naturally cause different effects and confusion. Therefore, the manipulative effect of fake news or information and the evaluation of the impact processes are of great importance. The purpose of this study is to explain the evaluation of fake news of individuals who may be exposed to fake news, to determine decision and impact processes, attitudes and behaviors in dealing with false news. This research is a descriptive field research using a quantitative research method. Survey is preferred as the data collection technique. Within the scope of the study a questionnaire was applied to 230 students studying at three universities in Ankara, Samsun and Eskisehir on a voluntary basis. The stratified sampling method, which is a probabilistic sampling method, was used in sample determination. In order to reveal the attitude and behavior patterns against fake news, the age range and gender variables of the sample representing the formal student population of three universities were taken into consideration. A questionnaire consisting of the use of media, the process of encountering fake news, the decision process of believing / not believing in the news, and verification is applied. As a result of the research, it was revealed that this sample found the visual content more convincing, false news with propaganda and guiding features was common, and it was common in magazine, politics and economy news types.

Keywords: Social media; fake news; fake news effect; fact-checking; audience attitudes and behaviors; misinformation; disinformation; malinformation; information pollution.

\section{Giriş}

Sosyal, siyasal, ekonomik ve toplumsal açıdan bilinç, tutum ve davranış geliştirme sürecinde etkili bir girdi olan haber, işlevleri bakımından önemli bir iletişim enstrümanıdır. Toplumsal açıdan mikro ve makro boyutta etkileri olan haber, en temel anlamıyla "ilginç ve güncel bir olayın olabildiğince nesnel ve gerçeğe uygun bir yolla sunulması" (Schlapp, 2002, s. 17) biçiminde tanımlanabilir. Haberin sunum sürecinde, "okuyucu ve dinleyici için öncelikle yeni gerçeklerle ilgili, doğru ve anlaşılır nitelikte olması" (Schneider ve Raue, 2002, s. 40) temel önem taşır. Sunum ve içeriğin yanı sıra, haberin kurgulanmış bir medya çıktısı olması, üretim sürecinde etkisi olan bireysel, ideolojik ve kurumsal yapılardan bağımsız olamayacağı gerçeğini de beraberinde getirmektedir. Medyanın sahiplik yapılarının devlet ve sermaye egemenliği ile olan doğrudan bağı nedeniyle medya metinleri ideolojik bir işleve sahiptir (Rigel ve Çağlar, 2010, s. 11) ve ideolojik görüşlerin dayatıldığı görsel/işitsel bir iletişim alanıdır (İnceoğlu ve 
Çoban, 2016, s. 24). Dolayısıyla haber, diğer medya metinlerine göre egemen yapıyla olan güç ilişkileri açısından daha yakın bir konuma sahiptir. Tam da bu konumundan dolayı haber üretim süreleri profesyonel bir meslek olarak tanımlanmış ve etik kodlar ile belirli kriterlere tabi tutulmuştur. Bu kriterlerin başında haberin nesnel olarak üretilmesi ve içeriğin net biçimde anlaşılabilir olması gelmektedir. Bunun amacı kuşkusuz haber içeriğinin çarpıtılmadan aktarılması ve doğruluğunun korunmasıdır.

Geleneksel medya ortamlarında yayımın düzenlenmesi sürecinin daha belirgin olarak işlemesi haber içeriklerinin daha denetimli olarak üretilmesini ve beraberinde bu içeriklerin sorumlularının açıkça bilinmesini görece daha olanaklı hale getirmektedir. Bu durum kısmen de olsa muhabir ve gazetecilerin sorumluluk duygularını artıran bir örgütsel yapılanma olarak değerlendirilebilir. Ancak, dijitalleşmenin etkisiyle değişen ve dönüşen iletişim pratikleri haber üretiminin daha esnek bir yapı içerisinde gerçekleşmesine olanak tanımaktadır. 1970'li yı1ların başında yeni medya olarak nitelendirilen ortam ve teknolojilerin ortaya çıkması, bireysel, örgütsel ve kitlesel iletişimin yeniden şekillenmesini beraberinde getirmiştir. Geleneksel medya ortamlarının tek yönlü-doğrusal merkezli yapısının aksine yeni medya ortamları kullanıcı merkezli bir iletişime olanak tanımaktadır. Bu bağlamda, kullanıcıya etkileşim ve katılım gibi olanaklar sunan yeni medya ortamları; aynı zamanda hızlı, anlık ve mobil iletişime olanak tanıyan yapısal özelliklere sahiptir. Kullanıcıların farklı türlerde (metin, video, ses ve görsel) içerikler üretmesine olanak tanıyan bu ortamlar, habercilik pratiklerinin de değişim ve dönüşüm geçirmesine yol açmıştır. Haber, içerik türlerinin yanı sıra güncellik, yayılım ve erişim olanakları ile yeni bir boyut kazanmıştır. Profesyonel ya da amatör olarak içerik üreticilerini aynı düzlemde bir araya getiren çevrimiçi platformlar, alternatif gazetecilik ve yurttaş gazeteciliği gibi kavramların doğuşuna da ön ayak olmuştur. Habere anlık, kolay ve ücretsiz erişim gibi olanaklar sağlayan bu gelişmeler, haberin nitelik açısından erozyona uğrama olasılığını da beraberinde getirmiştir. Profesyonel gazeteci olan ya da olmayan kişilerce üretilen haberlerin çevrimiçi platformlarda ve sosyal ağlarda büyük bir hız ve hacim ile yayılması, bu haberlerin nitelikleri, doğruluğu, vatandaşların haber okuryazarlığı ya da haber içeriğini eleştirel olarak analiz etme ve değerlendirme yeteneği (Craft, Ashley, ve Maksi, 2016) üzerinde daha çok durulması gerekliliğini doğurmuştur. Auberry (2018) gibi bazı araştırmacılara göre demokrasi, insanların gerçeği kurgudan ayırma ve bilgi olarak gizlenen iknaları tanıma becerisine bağlıdır. Bununla birlikte giderek kutuplaşan siyasi iklimler ve yalan haber (fake news) artışı, bu haberleri tanıma becerisi hakkında endişelere yol açmaktadır (Figueira ve Oliveira, 2017). Kamunun medyaya güveninin azalmasının (Ingram, 2018) temelinde, güvenilir bir haber kaynağını neyin oluşturduğuna dair ortak bir anlayışın eksikliği yatmaktadır.

Son zamanlarda yanlış bilgi (misinformation) ve yalan haber gibi fenomenler yeni olmamalarına rağmen (Mansky, 2018) daha fazla anılır olmuştur. Bununla birlikte gerçek sonras1 (post-truth) (Wang, 2016) ve yalan haber (Hodges, 2018) gibi terimlerin kullanımında bir artış söz konusudur. Haberin güvenirliğindeki belirsizlik ortamı, geleneksel haber medyasından uzaklaşarak hız kazanmaktadır. Örneğin, Mitchell'e göre (2018) Amerika'da daha çok insan, özellikle gençler haber kaynağı olarak internete ve sosyal medyaya güvenmektedir. Bunun aksine bazı sosyal medya araştırmaları da (Barthel, Mitchell ve Holcomb, 2016; Jang ve Kim, 2018) sosyal medya platformlarının doğrulanmamış ya da yanlış bilgilerin yayılmasını desteklediğini göstermektedir. 


\section{Yalan Haber ve Sosyal Medya}

Yalan (fake) sözcüğü, iletişim alanı odağında değerlendirildiğinde, "yanıltma, aldatma ve manipüle etme amaçlı alıcıya iletilen mesaj, yalan olarak nitelendirilmektedir" (Uluk, 2018, s. 57). Akaş ise yalanı, bilişsel bir perspektifle "bir bilinç durumu" olarak tanımlamakta; bilmeden yalan söylenemeyeceğini ancak yanlış bir şey söylenebileceğini ve yalan söyleyenin "mutlak doğru'yu bilmeksizin kendi doğru bildiğini bilinçli olarak çarpıtmasının yeterli olduğunu vurgulamaktadır (1998, s. 230). Yalan haber kavramı, yalanın ya da yanıltmanın haber metinleri aracılığıyla ve kitlesel ölçekte kurgulanarak yayımlanması sonucunda ortaya çıkmaktadır. Reuters tarafından yayınlanan bir araştırma raporunda (2017) yalan haber, "gazetecilik ilkeleri altında toplanan bilgiler gibi görünen, tamamen yanlış ya da yanıltıcı bir içerik" olarak tanımlanmıştır. Allcott ve Gentzkow, yalan haberi, kasıtlı ve yanlışlığı onaylı, okuyucuları yanlış yönlendirebilecek haber bilgileri olarak değerlendirmiş ve yalan haber üretiminin temelinde finansal ve ideolojik olmak üzere iki temel motivasyon olduğunu belirtmiştir. Yalan haber üreticileri, birilerini itibarsızlaştırmak, taraf oldukları kişileri saygınlaştırmak ya da belirli fikirleri yaygınlaştırmak için yalan haberi kullanabilir. Bunun temelinde bir taraftan şok edici ya da olağandışı olmaları nedeniyle virüs gibi hızlı bir biçimde yayılmaları; diğer taraftan teknoloji dolayımla güncel erişim pratikleri içerisinde tıklanmaya bağlı olarak içerik üreticilerinin reklam gelirine dönüşebilmeleri bulunmaktadır (2017, s. 213). Bu noktada gazetecilik pratiğinde, haber düzenlenirken aldatıcı bilgiyle sarmak, olayları yanlış tasvir etmek, haber icat etmek gibi uzun bir geçmişe sahip uygulamaların özellikle yüksek kaygı, kriz, çatışma ve devrim zamanlarında yaygın olarak kullanılan haber formları olduğunu (Kiernan, 2017) belirtmek yerinde olur.

Derakhshan ve Wardle, yalan haber kavramını bilgi kirliliği temelinde ele almış ve bilgi bozukluğunu, filtre balonu ve yankı odalarını kapsamlı bir şekilde incelemiştir (2017, s. 5). Buna göre çağdaş sosyal teknoloji "kirli” mesajları oluşturmak, yaymak ve tüketmek için karmaşık bir motivasyon ağı oluşturmaktadır. Ayrıca çok çeşitli içerik türleri ve teknikleri, bu içerikleri barındıran ve çoğaltan sayısız platform sağlamaktadır. Onlara göre yalan haber deyimi yerine bilgi kirliliği deyimi daha uygundur. Çünkü yalan haberin anlamı bilgi kirliliğinin yanında oldukça sınırlıdır ve siyasiler tarafından haber organizasyonlarını tanımlayan uygunsuz bir yapıya büründürülmüştür. Dolayısıyla özgür basın sıkıştırılabilen, kısıtlı, zarar görebilecek ve alt edilebilecek bir yapıya dönüştürülmektedir. Bu nedenle Derakhshan ve Wardle, bilgi bozukluğunu üç farklı türde sorgulamaktadır:

- Misenformasyon (misinformation), zarar verme kastı olmayan yanlış bilgi paylaşımıdır.

- Dezenformasyon (disinformation), zarar vermek için kasıtlı olarak yanlış bilgi paylaşımıdır.

- Kusurlu bilgilendirme (malinformation), genellikle gizli kalması için tasarlanan gerçek bilgileri kamusal alana taşıyarak, zarar vermek için paylaşılmasıdır.

Kişilerarası iletişimde yalan ve çarpıtma, retorik, propaganda ve kitle iknaları kadar eskidir. Farklı olan tarafı baskın Facebook ve Twitter gibi dijital platformlarda yanlış bilgilerin hızı, boyutu, muazzam çoğalması ve yaygın tüketimidir. Geleneksel haber kuruluşları tarafından ortaya konulmayan bilgiler, yaygın olarak kullanılan bu platformlarda geniş yer bulmuştur ve kolayca erişilebilir olmuştur. Yanlış bilgilendirme ile karmaşa yaratmayı, kamuoyu ve seçim sonuçlarını etkilemeyi amaçlayan devletler ve istihbarat teşkilatları, sosyal 
medyayı kontrol altına almıştır (Bennett ve Livingston, 2018). Yanlış, eksik ya da kusurlu bilgilendirme kamusal düşünceyi etkilemeye yeni bir boyut kazandırmıştır. Yalan haber ve yanlış bilgiler sadece propaganda amaçlı üretilmemiş, aynı zamanda kusursuz ve kar sağlayan yeni gelişmelere kapı açmıştır. Ticari girişimci aktörlere ilham vermiş, ABD'de seçmenlerin kararlarını etkilemiştir (Waisbord, 2018, s. 1867). Yalan haber paylaşımı, eskiden bir aldatma stratejisi olarak işlev görürken, içinde bulunduğumuz dijital zamanda özellikle siyasette sosyal medya üzerinden eleştirilere karşı kullanılan bir silaha evirilmiş ve bu kullanım çoğu ülkede yaygınlaşmıştır. (Erlanger, 2017). Kullanıcılar, sosyal medya hesapları aracılığıyla, ilk elden şahit oldukları haber değeri taşıyan olaylar hakkında bilgi, fotoğraf, video ve anlatım gönderebilme olanağına sahip olmuştur (Hermida, 2011; Jewitt, 2009). Başlangıçta, gazeteciler çevrimiçi ortamlarda yer alan okur kitlesinin izini sürmüş ve farklı bir platform olarak sosyal medyada görünürlüğünü artırmış; sonra sosyal medyada haberi ilk duyuran olmak ve izleyiciyle etkileşimde bulunmak için bu platformu kullanmaya yönelmiştir (Tandoc ve Vos, 2015). Hermida (2010) tarafından Twitter'ın bunun için çok uygun bir platform oluşturduğu ifade edilmektedir. Sosyal medya sadece haber dağıtımını değiştirmekle kalmamış, haberin nasıl görünmesi gerektiğine dair geleneksel kalıplara meydan okumuştur (tweetlerin haber gibi kabul görmesi). Çok katmanlı içeriklerden oluşan sansasyonel içeriklerin yayılması hız kazanmıştır. Bunların getirisi olarak yalan haber ve hakikatin önemini yitirdiği (post-truth) haberlere, eskiden olduğundan daha çok dikkat edilmeye başlanmıştır (Glasser, 2016). Küresel boyutta kaliteli araştırmacı gazetecilikte yükseliş (Schiffrin, 2014), veri gazeteciliği ve doğruluk kontrolü hareketi (fact-checking movement) (Graves, 2016) gibi örnekler gerçeği dikkatle belgeleyen haberlere olan ilgi artışının bir göstergesi olarak düşünülebilir.

Günümüzde yalan haber geçmişteki tanımlamalarından farklılaşan bir moda sözcük konumuna gelmiştir. Geçmişte haber taklidi, siyasi yergi ve propagandalar gibi anlamlar yüklenirken şimdilerde uydurma haberleri ifade eden bir role bürünmüştür. Bu haberler bazı haber kuruluşlarının eleştirel raporlarını itibarsızlaştırmaya ve bunların etrafındaki söylemleri bulanıklaştırmaya yardım etmektedir (Tandoc, Jenkins ve Craft, 2018).

Sosyal ağlarda, hukuki düzenlemelerin eksikliği ve uygulanma güçlüğü, kitlelerin kolayca (kitle psikolojisinin) yönlendirilebilmesini, kışkırtılabilmesini desteklemesi sosyal medyanın önemli dezavantajları arasında yer almaktadır. Disiplinsiz gelişen haber ya da bilgi süreci doğal olarak farklı etkilere, kaos ve karmaşaya neden olabilmektedir. Bu nedenle, yalan haberlerin ya da bilgilerin yönlendirici etkisi ve etki süreçlerinin değerlendirilmesi büyük önem taşımaktadır. Haber ve gerçeklik kavramları, gerçekliğin doğru tasvirlerinden ziyade, insanların bu bilgi ile ne yaptıklarıyla yakın ilişkidedir.

\section{Gazetecilik Pratikleri ve Yalan Haber}

Sosyal ağların, anlık, hızlı ve ekonomik haber/bilgiye erişim sağlaması, haber üretimi ve dolaşımını kolaylaştırması, niceliksel bir patlamaya yol açarken, içerik ürünlerinin niteliksel çöküşünü de beraberinde getirmiştir. Hatta hız özelliğini fırsat bilen özel ve tüzel hesapların kötü niyetli kullanımları, çevrimiçi ortamları, özellikle de sosyal ağları yalan haber barındırma açısından olumsuz bir üne kavuşturmuştur. Pepp ve arkadaşları (2019) araştırmalarında, sosyal medyada yalan haber paylaşmanın bir karakteristik oluşturma yolunda ilerlediğini belirterek, yalan haberlerin genel gazetecilik pratiklerinin dışında üretilmesine karşılık, öyle üretilmiş gibi yayan kişilerin kullandıkları/işledikleri haberler olarak değerlendirmektedirler. Ayrıca bunlar, 
haber statüsünde görülseler de gerçek haberler gibi üretilmediklerinden dolayı gerçek haber niteliğini yitirmiştir. Bunu, haber, yaygınlık, genel gazetecilik pratikleri ve işleyişe dayandırırlar. Haber, gerçek ya da hayali olayların herhangi bir anlatımını kapsar. Haberi okuyan ya da haber olarak gören kişi sayısı yani yaygınlık haberin ilgi alanına göre değişir; yerel, ulusal ya da uluslararası dolaşım olarak düşünülebilir. Gazetecilik, bir toplumun üyelerinin kendileriyle ilgili olaylar hakkında bilgilendirmeye odaklı faaliyetlerdir; kademeli tarihsel kökenleri ve öncüleri olan dinamik bir sosyal kurumdur. Haber işleyişi de haberin üretildiği biçim olarak yalan haberi anlamada önem kazanmaktadır. Bu konuda benzer görüşe sahip Kiesling (2015) "bir şeye belli bir özelliğe sahipmiş gibi davranmak ile bu özelliğe sahip olduğuna inanmanın aynı şey olmadığıı”" ve bir haberi aktarırken haberdeki bir özelliği zihinsel seviyelerde ön plana çıkartmanın doğruluk hissini güçlendirebileceğini belirtmiştir. Özet olarak yalan haberler gazetecilik pratikleri ile örtüşerek yol alsa da bu durum bunların gazetecilik pratikleri tarafindan üretildiğine inanmayı gerektirmez. Yalan haberleri üreten ve tüketenlerin gerçekte onlara ne kadar inandıkları ya da gerçek gazetecilik örnekleri oldukları muğlaktır. Ancak yalan haberin sosyal medya tüketicileri tarafından gerçek gazetecilik pratikleri olarak üretilmiş gibi algılanması, siyasi düşmanlıklara bir silah olarak ya da yanlılığı pekiştirici etki oluşturabilir. Ayrıca yalan haberlerin büyük ölçüde yanlış olmasını da gerekmez. Diğger taraftan bu yalan haber tanımı, haber kaynağının ya da yayanların bir aldatma ya da yanıltma niyetinin olmasını gerektirmediğini de kapsamaktadır. Hatta haber kaynağının ya da bunu yayanların bir yanıltma ya da aldatma niyeti de olması gerekmez. Tüm bunlar, haber üretim sürecinin yani profesyonel haberciliğin, haberin niteliği açısından taşıdığı önemi artırmakta ve okurlar ya da yeni medya ortamlarında üre-tüketiciler tarafindan haberin kaynağının göz önünde bulundurulması gerekliliğini ön plana çıkarmaktadır. Ayrıca reklam gelirine dayanan endüstri, kâr payı yüzünden arama motorlarında ilk çıkmak için bir yarış içerisine girmiştir. Hız ve tık endişesi haber kalitesizliğini desteklemektedir. Odaklanılan çok sayıda içerik üretimi, etik ilkeleri göz ardı etmeye hayatta kalmak için gereken geliri elde etme mücadelesine dönüşmektedir. Dolayısıyla tıklanma tuzaklarına ya da yalan habere maruz kalma, medyadaki güvensizliği tırmandırmaktadır. Reuters'nn yayınladığı 2020 raporuna göre, küresel anlamda habere olan güven bir önceki ylla göre $\% 2$ gerilemiş ve $\% 42$ 'ye düşmüştür. Raporda Türkiye'de ise genel olarak haberlere güven $\% 46$, sosyal medya haberlerine güven ise $\% 40$ oranındadır (Newman, Fletcher, Schulz, Andı ve Nielsen, 2019, s. 9-115).

Yalan haber ve sosyal medya ilişkisinde üzerinde durulması gereken en önemli noktalardan bir tanesi de sosyal ağların işleyiş mantığının dayandığı algoritmalardır. Algoritma, matematiksel olarak "bir problemin çözümü için kullanılan sonlu kurallar kümesi" (TSE, 2006, s. 6) olarak tanımlanırken "arama sonuçları oluşturma gibi bir görevi yerine getirmek için kullanılan bir dizi talimat veya prosedür" (Kalsın, 2018, s. 16) olarak da açıklanmaktadır. Sosyal ağlarda algoritmaların etkisi, kullanıcıların yeni teknolojilerle birlikte sunulan kişiselleştirilmiş bir kullanıcı deneyimi adına gerçekleştirdikleri işlem trafiği üzerinden değerlendirilebilir.

Kullanıcıların çevrimiçi davranışları, çerez olarak isimlendirilen tanımlama dosyalarıyla takip edilmekte, bu davranışları sırasında bıraktıkları ayak izlerine bağlı olarak arama sonuçları/içerikler sunulmaktadır. Bundan dolayı kullanıcılar, sadece kendi ilgi duydukları ya da etkileşim halinde oldukları kişi, hesap ya da içeriklerle karşılaşmaktadır. Bu durum, Pariser 
(2011) tarafından "filttre balonları" olarak kavramsallaştırılmıştır. Filtre balonları, ağ içerisinde kullanılan algoritmalar tarafından bir kullanıcının belirli kriterler üzerinden tanımlayan ya da kişiyi temsil eden sembolik bir kimlik olarak açıklanabilir. Bu kimlik yardımıyla sosyal ağlarda kişi ve kişinin kullanıcı olarak sergilediği davranışlara benzer hesaplar ona önerilmektedir. Filtre balonları, kullanıcıların kendi zaman akışlarını oluşturabilmesine olanak tanımakta, onları kendi mevcut görüşlerini pekiştiren bilgiye maruz bırakmakta, bilgiye daha fazla erişim de ideolojik olarak uyumlu içeriğe seçici olarak maruz kalmayı teşvik etmektedir. Bunların sonucunda sosyal aşırılık ve siyasi kutuplaşmayı kolaylaştırabilecek bir "yankı odası" (echo chamber) ortamına yol açabilmektedir (Iyengar ve Hahn, 2009; Prior, 2007; Adamic ve Glance, 2005). Yalan haber sosyal medya ilişkisi bağlamında yankı odaları, var olan görüşün pekiştirilmesini sağlamakta, görüşe ait inancı güçlendirerek karşıt görüşlere yer vermemektedir. Dolayısıyla, birey farklı fikirlere ve eleştirilere kapalı yani sansürlenmiş bir atmosferde sıkışıp kalabilir. Bunun sonucunda farklı yaklaşımlarla etkileşime geçemez, karşı karşıya kaldığı içerikler hakkında sorgulayıcı bir tutum geliştirmez ve gerçeklikten uzak, süregelen bir yanılgı döngüsünün içine düşmüş olur.

Yalan haber ya da bilgilere kapı aralayan bir diğer faktör "aşırı bilgi yoğunluğudur". Sınırlı sayıda bilgi işlemeye ve depolamaya uygun şekilde evrimleşen insan beyni, internet hızıyla ve kapsamıyla yükselen bilgiyi tüketmekte zorlanmaktadır. Aşırı bilgi, doğru ve yanlış bilginin ayırdına varmayı zorlaştırmakta, körleştirmekte ve haberden/bilgiden kaçınma eğilimine yol açmaktadır (Silvestre, 2018). Aşırı bilgi yoğunluğunun yanı sıra internetin alt kültürlerinde yetişen trol aktiviteleri (Taiwo, 2014) zamanla yanlış bilgi, nefret söylemi, ayrımcılıkla hedef gösterme konularında etkili olabilmektedir. Ayrıca bir program aracılığında üretilen, gerçek olmayan ve belirli bir gündemi ön plana çıkaran hesapların artması (botlar), sosyal medya platformlarında gerçek bilgilerin baskılanmasına neden olabilmektedir (Shu, 2017; Ferrara, 2016 çalışmasından aktaran Taş ve Taş, 2018, s. 196). Diğer taraftan sahte haberleri tüketen ve yayanların gerçekte onlara ne kadar inandıkları ya da bu içeriklerin ne kadarının gerçek gazetecilik örnekleri oldukları muğlaktır. Bu nedenle, medya okuryazarlığının önemli bileşenlerinden biri olan haberin kaynağının ve doğruluğunun teyit edilmesi büyük önem taşımaktadır.

Yalan haber konusunda sosyal medya kullanıcısının kendine özgü sıkıntılarından da söz edilebilir. Birey kendi inandiğı ve kendi düşüncelerini destekleyen bilgileri onaylayabilmektedir. Ötekileştirme, biz ve onlar ikilemine indirgeme ya da kutuplaşma farklı görüşteki bireylerle aynı ortamda bulunma olasılıklarını azaltmaktadır. Yeni medya okuryazarlığı becerilerinin ve eğitim düzeyinin yetersizliği eleştirel düşünce gelişimini sınırlandırmaktadır. Öte yandan medya kurumlarının tekelleşmesi ve totaliter rejim baskısı doğru bilgi yayılımını etkileyebilmektedir.

\section{Doğruluk Kontrolü}

Medya metinlerine ya da daha özelinde haber metinlerine doğruluk kontrolü uygulanması yaklaşık 300 yılı aşkın bir geçmişe dayanmaktadır. Çevrimiçi olarak geleneksel örnekleri, ABD'de yayınlanan dergilerde istihdam edilen düzeltmenlerle karşımıza çıkan doğruluk kontrolü uygulamas1; “Snopes ve Smoking Gun” gibi sitelerle 1990'l1 yıllarda başlamıştır. Ardından 2003 yılında Pennsylvania Üniversitesi'nin bir projesi olarak "FactCheck.org” tam zamanlı (siyasi doğruluk) kontrole başlamıştır (Fabry, 2017). Bunlar medya ve çevrimiçi 
içeriklerin tümünde, toplum üzerinde etkili toplumsal ya da siyasi aktörlerin söylemlerinin doğru olup olmadığını kanıtlarla ortaya koyan çalışmalardır. Doğruluk kontrolü yapan merkezlerin ya da diğer bir deyişle doğrulatma platformlarının amacı; kamuoyunun ilgisini çeken ve şüphe uyandıran haberlerin, belirli bir yöntem dahilinde farklı kaynaklardan bilgi karşılaştırması yaparak doğru ya da doğru olmadıkları konusunu kamuoyuyla paylaşmaktır (Kocabay, 2018, s. 361). Günümüzde dijital platformlar üzerinden gerçekleştirilen doğruluk kontrolleri belirli bir içeriğin bildirilmesi üzerinden oluşturulan bir talep ile uygulanmaya başlamışıı. Doğrulama platformlarının ülkemizdeki ilk örneği 2009 yllında kurulan "yalansavar.org" olurken bu platformu, 2014 yılında "dogrulukpayi.com"; 2016 y1linda ise "teyit.org" takip etmiştir. Bunların yanı sıra son zamanlarda yalan bilgiye duyarlı kullanıcıları sosyal medya platformlarında bir araya getirerek kolektif mücadeleyi teşvik eden platformların geliştirilme çabalarından söz edilebilir (Ör., http://geppetto.io).

Sosyal ağlarda dolaşıma giren içeriklerin/haberlerin doğruluğunun yayılım hızı ve erişim hacmi nedeniyle taşıdı̆ı önemin fark edilmesi sonucunda sosyal ağlarda işaretleme uygulamaları üzerinde çalışılmıştır. Mena (2019) çalışmasında insanların yalan haber paylaşımında bulunmaktan caydırılması için bu haberlerin işaretlenmesi önerisinde bulunulmakta, böyle bir uygulamanın yalan haberleri azaltmada etkili olacağını ve yayılmasına bir sınırlama getireceğini vurgulamaktadır.

Sosyal ağlar ve güncel iletişim teknolojileri doğrulatma platformlarının hayatımıza girmesine de imkân tanımıştır. Bununla birlikte kullanıcının yüksek etkileşim ve katılım düzeyine sahip olması da bir diğer teyit mekanizması olarak değerlendirilebilir. Kullanıcı, doğruluğundan şüphe duyduğu içerikler hakkında kendi karar verir, doğru bulmadığı içerikleri şikâyet mekanizması yardımıyla ifşa etmek suretiyle de bu içeriklerin yayılmasını etkileyebilir. Wardle'a göre (2017) kullanıcı, yalan haberi üreten haber sitelerinden ziyade kendi aile ve arkadaş çevrelerini kapsayan ağlar vasıtasıyla, dezenformasyon kampanyalarının etkisinde kalabilen, bilinçsiz bir şekilde yanıltıcı ve uydurulmuş içerikleri paylaşmak suretiyle, yalan haberin yayılımı noktasında etkin bir oyuncu rolündedir. Dolayısıyla doğruluk teyidi konusunda bireylerin bilinçlenerek geliştirebilecekleri tedbirler önemsenmeli ve teşvik edilmelidir.

\section{Araştırmanın Amacı}

$\mathrm{Bu}$ araştırmanın temel amacı haberlerin internet ortamında erozyona uğramasına bağlı olarak, kurumların ve toplumun bünyesinde olası kötü niyetli aktörlerin manipülasyonlarına maruz kalabilen bireylerin kaynak değerlendirmesini açıklamak, bu ortamlardaki bilgiler hakkında karar süreçlerine yardımcı olacak fikirler sağlamaktır. Bu bağlamda bireylerin yalan haber hakkında bilinç, korunma yöntemleri ve bu haberlerin yayılma mekanizmaları değerlendirilmektedir. Bu doğrultuda belirlenen araştırma soruları şöyledir:

- Sosyal medyada haber ve bilgiler hakkında karar süreçlerini neler etkilemektedir?

- Bireyler sosyal medyada maruz kaldıkları (yalan) haberlerden nasıl etkilenmektedir?

- Bireylerin sosyal medyada yalan habere/bilgiye karşı tutum ve davranışları nasıldır?

\section{Araştırmanın Yöntemi ve Tasarımı}

$\mathrm{Bu}$ araştırma, yalan haberlerin yükselişine bağlı olarak bireylerin bu duruma karşı geliştirdikleri tutum ve davranışları ortaya çıkarma girişimi olduğundan, yapıldığı çevreye göre 
gerçekleştirilen açıklayıcı/tanımlayıcı bir durum araştırmasıdır. Üniversite öğrencilerinin yalan haber algılarına odaklanılmakta, veriler doğrultusunda algıların neler olduğuna bakmakta ve gelecek araştırmalar için daha detaylı nelere odaklanılması konusunda değerlendirmeler ortaya koymaktadır (Davey, 1990). Örneklemdeki bireyler, sosyal medya kullanıcısı üniversite öğrencilerinden oluşmaktadır. Bu durum araştırmasında örneklemdeki öğrencilerin, sosyal medya ortamında maruz kaldıklarını düşündükleri haber/bilgi durumu aydınlatmak, özellikleri doğrultusunda değerlendirmeler yapmak ve olaylar arasında olası ilişkileri ortaya çıkarmak için gönüllülük esasına dayalı yüz yüze anket tekniği kullanılmakta ve incelenen durum etraflıca tanımlanarak açıklanmaktadır. Araştırmanın yapılabilmesi için Anadolu Üniversitesi Sosyal Bilimler Bilimsel Araştırma ve Yayın Etiği Kurulu'ndan (29.04.2019) etik onay alınmıştır.

\section{Evren ve Örneklem}

Çalışma ana kütlesini Anadolu Üniversitesi (Eskişehir), Başkent Üniversitesi (Ankara) ve Ondokuz Mayıs Üniversitesi'nde (Samsun) farklı bölümlerde örgün öğrenim gören 81796 öğrenci oluşturmuştur. Bu üniversitelerdeki öğrenci evrenini temsil edebilecek öğrenci örneklemi olasılığa dayanan örnekleme yöntemi olan tabakalı örnekleme yöntemi kullanılarak belirlenmiştir (Yıldırım ve Şimşek, 2005, s.105). Üç üniversiteden evreni temsil edebilecek oranlama sonucunda basit tesadüfi örnekleme ile seçilen toplam 230 öğrenciden veri toplanmıştır.

Tablo 1

Tabakalı örneklem hesaplama $(n=230)$

\begin{tabular}{llcrr}
\hline Tabaka & Üniversite & Öğrenci sayısı & Tabaka ağırlığı & $\begin{array}{r}\text { Örnekleme girecek } \\
\text { öğrenci sayısı }\end{array}$ \\
\hline 1 & Anadolu Üniversitesi & 22684 & 0,28 & 64 \\
2 & Başkent Üniversitesi & 12577 & 0,15 & 35 \\
3 & Ondokuz Mayıs Üniversitesi & 46540 & 0,57 & 131 \\
\hline & Toplam & 81796 & 1,00 & 230
\end{tabular}

Örneklem genç kuşağın temsilcisi olan teknolojiye daha yakınlık duyan sosyal medyada daha çok zaman geçiren ve yüksem eğitim düzeyine sahip üniversite öğrencilerinden oluşmaktadır. 230 katılımcının 115'i kadın, 115'i erkektir. Katılımcı öğrencilerin yaşları, 18 ile 30 arasında değişmektedir ve yaş ortalaması 21'dir (standart sapma=1,91) ve bu öğrenciler farklı fakülte ve bölümlerdedir. Araştırma katılımcılarının \%28'i Anadolu Üniversitesi, \%57'si 19 Mayıs Üniversitesi ve \%15,2'si Başkent Üniversitesi öğrencisidir. Katılımcıların \%58,7'si ön lisans, \%40,4'ü lisans, \%0,9'u yüksek lisans düzeyinde eğitim gören öğrencilerden oluşmaktadır (bkz. Tablo 2). 
Tablo 2

Katılımcıların demografik özellikleri

\begin{tabular}{llrr}
\hline & & $\mathrm{n}$ & $\%$ \\
\hline Öğrenci, (n=230) & Kadın & 115 & 50 \\
& Erkek & 115 & 50 \\
\hline Yaş aralıkları & $18-19$ & 37 & 16,1 \\
& $20-21$ & 117 & 50,8 \\
& $22-23$ & 51 & 22,2 \\
& $24-25$ & 19 & 8,2 \\
& $26-27$ & 4 & 1,8 \\
& $28-29$ & 1 & 0,4 \\
& 30 & 1 & 0,4 \\
\hline Ĕgitim düzeyi & Ön lisans & 135 & 58,7 \\
& Lisans & 93 & 40,4 \\
& Yüksek Lisans & 2 & 0,9 \\
& Doktora & 0 & 0 \\
\hline
\end{tabular}

Verilerin toplanması ve değerlendirilmesi: Geliştirilen anket formları üç üniversitede toplamda 230 kişiye uygulanmış, anket sonuçları SPSS paket programında değerlendirmeye alınmıştır. Sonuçlar, sıklık ve aritmetik ortalamaları (1-5 aralığı) üzerinden değerlendirilmiştir (bkz. Tablo 3).

Tablo 3

Gruplara göre aritmetik ortalamalar

\begin{tabular}{lrrr}
\hline Etki ortalamaları & Ort. (mean) & $\mathrm{n}$ & Std. sapma \\
\hline Başkent Üniversitesi & 3,7086 & 35 & 0,71676 \\
Anadolu Üniversitesi & 3,9062 & 64 & 0,49630 \\
Ondokuz Mayıs Üniversitesi & 3,5985 & 131 & 0,69082 \\
Toplam & 3,7009 & 230 & 0,65784
\end{tabular}

Verilerin normal dağılım gösterip göstermediği betimsel yöntemler olan değişim katsayısı, çarpıklık ve basıklık istatistikleri üzerinden incelenmiştir. Çarpıklık ve basıklık katsayılarının \pm 1 sınırları içinde 0'a yakın olması, çarpıklık ve basıklık katsayılarının kendi standart hatalarına bölünmesi ile hesaplanan çarpıklık $(0,32)$ ve basıklık $(0,43)$ indekslerinin \pm 2 sınırları içinde 0'a yakın olması, standart sapma ile ortalamanın oranını yüzde olarak ifade eden bağıl değişim katsayısının $(0,17)$ yüzde 25 'den küçük olması normal dağılımın varlığına kanıt olarak değerlendirilmiştir (Tabachnick ve Fidell, 2013) (bkz. Tablo 4). Ayrıca histogram gözlemi çan eğrisi şeklindedir. Verilerin normal dağılıma uyum göstermesi parametrik testlere imkân sağlamaktadır. 
Tablo 4

Tanımlayıcılar

\begin{tabular}{lrr}
\hline Etki ortalamaları & İstatistik & Std. hata \\
\hline Aritmetik ortalama (mean) & 3,7009 & .04338 \\
\%95 Güven aralığı (lower bound) & 3,6154 & \\
\%5 Ayarlanmıs ortama (upper bound) & 3,7863 & \\
Medyan & 3,7542 & \\
Varyans & 0,433 & \\
Std. Sapma & 0,65484 & \\
Minimum & 1,80 & \\
Maksimum & 5,00 & \\
Oran (range) & 3,20 & \\
Çeyrekler arası aralık (Interquartile Range) & 0,80 & \\
Çarpıklık & $-0,502$ & 0,160 \\
Basıklık & 0,439 & 0,320 \\
\hline
\end{tabular}

$\mathrm{Bu}$ araştırma sonuçlarının, pratikteki anlamlılığının bir göstergesi olan etki büyüklügüü hesaplanmıştır. Veriler normal dağılım gösterdiğinden ikiden fazla grup için etki büyüklüğü hesaplaması için grup büyüklükleri eşit olmadığından tek faktörlü Anova testi (eta kare (ๆ2) hesaplanmas1) yapılmıştır ( $\eta 2=$ gruplar aras1 kareler toplamı/kareler toplam1, 4,075/99,100 $=0,041$ ). Etki büyüklüğü (d) 0,041'dir. Bu etki değerinin anlamlılık derecesi Cohen (1988) sınıflamasına göre değerlendirildiğinde 0,2 'den küçük olması $(\mathrm{d}<0,2)$ durumuyla etki büyüklüğü zayıf olarak tanımlanabilir. Gruplar arasındaki mutlak fark azdır (bkz. Tablo 5).

Tablo 5

Tek faktörlü ANOVA/Etki ortalamaları

\begin{tabular}{lcrrrrr}
\hline & $\begin{array}{c}\text { Kareler } \\
\text { toplamı }\end{array}$ & $\begin{array}{c}\text { Serbestlik } \\
\text { derecesi (df) }\end{array}$ & $\begin{array}{c}\text { Kareler } \\
\text { ortalaması }\end{array}$ & $\begin{array}{c}\text { F } \\
\text { Anlamlılık } \\
\text { düzeyi (p) } \\
\text { (Sig.) }\end{array}$ & $\begin{array}{c}\text { Etki } \\
\text { büyüklüğü }\end{array}$ \\
\hline $\begin{array}{l}\text { Gruplar arasında } \\
\text { (Between groups) }\end{array}$ & 4,075 & 2 & 2,038 & 4,868 & 0,009 & 0,041 \\
$\begin{array}{l}\text { Gruplar içinde } \\
\text { (Within groups) }\end{array}$ & 95,025 & 227 & 0,419 & & \\
Toplam & 99,100 & 229 & & & & \\
\hline
\end{tabular}

Anket formlarının hazırlanması: Araştırmaya katılan öğrencilerin yalan habere karşı geliştirdikleri tutum ve davranışları ortaya çıkarmak amacıyla bir anket formu hazırlanmıştır. Araştırma anketinde demografik bilgi sorularının ardından katılımcının yalan habere bakışını ölçmeye yönelik sorular 5'li likert tipinde toplam 53 sorudan oluşmaktadır. Sorular en az 1 ve en çok 5 aralığında derecelendirilmiştir. Araştırma anketi demografik bilgileri ölçen soruların haricinde dört temel kategoriden oluşmaktadır: 
- Medya kullanımı

- Habere (yalan) maruz kalma süreci (haber elemanları, içerikleri ve konuları, özellikleri) süreci.

- Habere inanma/inanmama karar süreci

- Doğruluk kontrolü.

Bu kategoriler, katılımcıların sosyal medya kullanımları; platform tercihleri, sosyal medya özelliklerinin yalan haber algısına etkileri, yalan haber ile karşılaşma durumları; yazı resim ve video gibi haber elamanlarının, haber içeriklerinin ve haber konularının bundaki rolü, şüphe uyandıran durumlar, karşılaş1lan yalan haber özellikleri, habere güveni etkileyen, inanırlığı destekleyen unsurlar ve doğrulatma davranışı; yalan olduğunu düşündükleri haberin teyitini engelleyen ya da teyit etmeye yönlendiren unsurlar ve bu konudaki tutumlarının belirlenmesi şeklinde açıklanabilir.

Geçerlik ve güvenirliği sağlama aşaması: Araştırma sonuçlarının inandırıcılığ açısından önemli ölçütlerden biri olan güvenirliği sağlama (Yıldırım ve Şimşek, 2005, s. 257) ve amaca hizmet etmesi için Cronbach's Alpha değeri bulunmuştur. Demografi sorularının haricindeki 49 sorunun Cronbach's Alpha değeri 0.841'dir. Sosyal bilim araştırmalarında Cronbach alfa katsayısının 0.60 ile 0.90 aralığında olması veri aracının oldukça güvenilir olduğu anlamına gelmektedir (Tavşancıl, 2002). Dolayısıyla 0,80 ile 1.00 arasında bulunan bu değer tam güvenilirlik ifade etmektedir.

\section{Bulgular}

Katılımcıların haber almak için kullandıkları mecranın tespit edilmesine yönelik elde edilen verilere göre, haber gereksinimleri geleneksel medyaya göre büyük ölçüde sosyal medyadan karşıladığı görülmektedir. Katılımcılar, çoğunlukla sosyal medyadan haber alma eğilimindedir (\%39,6 ve \%50,9). Katılımcıların, bazen \%40 oranında geleneksel medyayı tercih ettikleri de tespit edilmiştir (bkz. Tablo 6). Sosyal medya kullanım oranı geleneksel medya kullanımına göre yüksektir $(\bar{x}=4,40)$.

Tablo 6

Katılımcıların medya kullanımları

\begin{tabular}{lcrcr}
\hline & $\begin{array}{c}\text { Sosyal medya } \\
(\overline{\mathrm{x}}=4,40)\end{array}$ & \multicolumn{3}{c}{ Geleneksel medya } \\
& $\mathrm{n}$ & $\%$ & $\mathrm{n}=2,96)$ & \\
\hline Hiçbir zaman & 2 & 0,9 & 12 & 5,2 \\
Çok nadir & 4 & 1,7 & 56 & 24,3 \\
Bazen & 16 & 7,0 & 92 & 40,0 \\
Çoğu zaman & 91 & 39,6 & 55 & 23,9 \\
Her zaman & 117 & 50,9 & 15 & 6,5 \\
\hline Toplam & 230 & 100 & 230 & 100 \\
\hline
\end{tabular}


Haber gereksinimlerini daha çok sosyal medyadan karşılayan katılımcıların büyük çoğunluğunun Instagram'1 $(\% 54,3)$ ve YouTube'u $(\% 42,6)$ kullandığı Facebook $(\% 42,2)$ ve Twitter'1 $(\% 38,7)$ daha az tercih ettiği sonucuna ulaşılmıştır (bkz. Tablo 7).

Tablo 7

Katılımcıların sosyal ăgları kullanma tercihleri

\begin{tabular}{lcrrrrrrr}
\hline & $\begin{array}{c}\text { Facebook } \\
(\overline{\mathrm{x}}=2,23)\end{array}$ & \multicolumn{2}{c}{$\begin{array}{c}\text { Instagram } \\
(\overline{\mathrm{x}}=4,17)\end{array}$} & \multicolumn{2}{c}{$\begin{array}{c}\text { Twitter } \\
(\overline{\mathrm{x}}=2,70)\end{array}$} & \multicolumn{2}{c}{$\begin{array}{c}\text { YouTube } \\
(\overline{\mathrm{x}}=4,06)\end{array}$} \\
\hline Hiçbir zaman & $\mathrm{n}$ & $\%$ & $\mathrm{n}$ & $\%$ & $\mathrm{n}$ & $\%$ & $\mathrm{n}$ & $\%$ \\
Çok nadir & 97 & 42,2 & 15 & 6,5 & 89 & 38,7 & 3 & 1,3 \\
Bazen & 53 & 23,0 & 10 & 4,3 & 21 & 9,1 & 20 & 8,7 \\
Çoğu zaman & 34 & 14,8 & 20 & 8,7 & 31 & 13,5 & 35 & 15,2 \\
Her zaman & 21 & 9,1 & 60 & 26,1 & 44 & 19,1 & 74 & 32,2 \\
\hline Toplam & 25 & 10,9 & 125 & $\mathbf{5 4 , 3}$ & 45 & 19,6 & 98 & $\mathbf{4 2 , 6}$ \\
\hline
\end{tabular}

Katılımcıların yalan haberlere maruz kalma değerlendirmeleri incelendiğinde; \%27'si nadiren, \%37'si bazen, \%21,7'sinin de çoğu zaman yalan haberle karşılaştığını belirtmiştir. Katılımcıların \%10’u hiçbir zaman yalan haberle karşılaşmadıklarını belirtmiştir (bkz. Tablo 8). Tablo 8

Yalan habere maruz kalma durumu değerlendirmeleri

\begin{tabular}{lrr}
\hline & $\mathrm{n}$ & $\%$ \\
\hline Hiçbir zaman & 23 & 10,0 \\
Nadiren & 62 & 27,0 \\
Bazen & 85 & 37,0 \\
Çoğu zaman & 50 & 21,7 \\
Her zaman & 10 & 4,3 \\
\hline Toplam & 230 & 100.0 \\
\hline$(\bar{x}=3,83)(S=1,01)$ & &
\end{tabular}

Katılımcıların çoğu, yazı, fotoğraf ya da video gibi haber elemanlarının bir haberin sahtelik şüphesi uyandırmasında önemli bir rolü olmadığını değerlendirmektedir. Diğer bir deyişle katılımcılara göre, haber elemanlarına dayalı içerik farklılıkları yalan haber olma şüphesini artırmamaktadır. Ancak elde edilen sonuçlardan, görsel niteliklerin yazıya göre daha az şüphe uyandırdığı dikkati çekmektedir. Bu durum fotoğraflı ve video vb. görsel nitelikli içeriklerin, (sadece) yazılı metne göre daha çok doğru kabul edildiğini ortaya koymaktadır. Fotoğraflı içerikler \%40,9 ve videolu içerikler \%44,3 oranında şüphe uyandırmamaktadır (bkz. Tablo 9). Sonuç olarak göz tanıklığının habere inanırlığı artırdığı görülmektedir. 
Tablo 9

Haber elemanlarının sahtelik şüphesi uyandırmadaki rolü

\begin{tabular}{|c|c|c|c|c|c|c|}
\hline & \multicolumn{2}{|c|}{$\begin{array}{l}\text { Sadece yazılı içerik } \\
\qquad(\bar{x}=3,42)\end{array}$} & \multicolumn{2}{|c|}{$\begin{array}{l}\text { Fotoğraflı içerik } \\
\qquad(\bar{x}=3,00)\end{array}$} & \multicolumn{2}{|c|}{$\begin{array}{l}\text { Videolu içerik } \\
\qquad(\bar{x}=2,87)\end{array}$} \\
\hline & $\mathrm{n}$ & $\%$ & $\mathrm{n}$ & $\%$ & $\mathrm{n}$ & $\%$ \\
\hline Kesinlikle katılmıyorum & 53 & 23,0 & 75 & 32,6 & 84 & 36,5 \\
\hline Katılmiyorum & 79 & 34,3 & 94 & 40,9 & 102 & 44,3 \\
\hline Kararsızım & 51 & 22,2 & 46 & 20,0 & 32 & 13,9 \\
\hline Katılıyorum & 41 & 17,8 & 15 & 6,5 & 12 & 5,2 \\
\hline Kesinlikle katılıyorum & 6 & 2,6 & 0 & 0 & 0 & 0 \\
\hline Toplam & 230 & 100.0 & 230 & 100.0 & 230 & 100.0 \\
\hline
\end{tabular}

Katılımcıların sık karşılaştıkları yalan haber türleri, en çok magazin $(\% 47,8)$ olmak üzere siyaset $(\% 41,3)$ ve ekonomi $(\% 30,9)$ haberleri olarak değerlendirilmektedir. Sağlık, bilimteknoloji ve eğitimde (yalan) haberler daha arka plandadır (bkz. Tablo 10).

Tablo 10

Katılımcıların sık karşılaştıklarını düsündükleri haber konuları

\begin{tabular}{lccccccccccc}
\hline & \multicolumn{2}{c}{ Hiç yok } & \multicolumn{2}{c}{ Çok az } & \multicolumn{2}{c}{ Bazen } & \multicolumn{2}{c}{ Çok } & \multicolumn{2}{c}{ Çok fazla } \\
\cline { 2 - 12 } & $\mathrm{n}$ & $\%$ & $\mathrm{~N}$ & $\%$ & $\mathrm{n}$ & $\%$ & $\mathrm{n}$ & $\%$ & $\mathrm{n}$ & $\%$ \\
\hline Siyaset $(\bar{x}=3,92)$ & 12 & 5,2 & 14 & 6,1 & 48 & 20,9 & 61 & 26,5 & 95 & $\mathbf{4 1 , 3}$ \\
Ekonomi $(\bar{x}=3,62)$ & 10 & 4,3 & 36 & 15,7 & 56 & 24,3 & 57 & 24,8 & 71 & $\mathbf{3 0 , 9}$ \\
Polis/adliye $(\bar{x}=3,49)$ & 13 & 5,7 & 35 & 15,2 & 60 & $\mathbf{2 6 , 1}$ & 70 & 30,4 & 52 & 22,6 \\
Magazin $(\bar{x}=4,00)$ & 13 & 5,7 & 21 & 9,1 & 29 & 12,6 & 57 & 24,8 & 110 & $\mathbf{4 7 , 8}$ \\
Sağlik $(\bar{x}=3,12)$ & 16 & 7,0 & 51 & 22,2 & 84 & 36,5 & 47 & 20,4 & 32 & 13,9 \\
Bilim ve teknoloji & 22 & 9,6 & 54 & 23,5 & 75 & 32,6 & 49 & 21,3 & 30 & 13,0 \\
$(\bar{x}=3,04)$ & & & & & & & & & & \\
Eğitim $(\bar{x}=3,26)$ & 21 & 9,1 & 37 & 16,1 & 76 & 33,0 & 52 & 22,6 & 44 & 19,1 \\
Diğer konular & 1 & 0,4 & - & - & - & - & - & - & - & - \\
\hline
\end{tabular}

Katılımcılar maruz kaldıkları yalan haberlerin özelliklerini şöyle değerlendirmektedir: İlk sırada çoğunluğun karşılaştığı yalan haberlerin daha çok propaganda ve yönlendirici özellikte $(\bar{x}=3,78)$ olduğu, ikinci sırada reklam amaçlı $(\bar{x}=3,60)$ olduğu değerlendirilmektedir. Ardından, kasıtlı amaç güden $(\bar{x}=3,57)$, kışkırtıcı $(\bar{x}=3,56)$ ve hiciv/alaycı $(\bar{x}=3,47)$ yalan haberler gelmektedir. Katılımcılar en az karşılaştıkları yalan haber türünü eğlence ve mizah özelliği olanlar olduğunu belirtmektedir $(\bar{x}=3,46)$. Diğer bir deyişle katılımcıya göre, en düşük yalan haber olma ihtimali eğlenceli ya da mizah özellikli haberlerdir (bkz. Tablo 11). Buna göre mizah içerikli haberlerin doğru kabul edilmesi, mizah içerikleri bilgi ve haberlerde ideolojik yüklemelerin katılımcı öğrencilerin büyük oranda şüphelenmeden kabulüne yol açma riskinin bulunduğunu ortaya koymaktadır. 
Tablo 11

Katılımcıların sık karşılaştıklarını düşündükleri yalan haber özellikleri

\begin{tabular}{lrrrrrrrrrrc}
\hline \multicolumn{1}{c}{ n=230 } & \multicolumn{2}{c}{ Hiç yok } & \multicolumn{2}{c}{ Çok az } & \multicolumn{2}{c}{ Orta } & \multicolumn{2}{c}{ Çok } & \multicolumn{2}{c}{ Çok fazla } \\
\hline & $\mathrm{n}$ & $\%$ & $\mathrm{~N}$ & $\%$ & $\mathrm{n}$ & $\%$ & $\mathrm{n}$ & $\%$ & $\mathrm{n}$ & $\%$ \\
\hline Kişkırtıcı $(\bar{x}=3,56)$ & 7 & 3,0 & 33 & 14,3 & 66 & 28,7 & 70 & $\mathbf{3 0 , 4}$ & 54 & $\mathbf{2 3 , 5}$ \\
Kasıtlı $(\bar{x}=3,57)$ & 7 & 3,0 & 28 & 12,2 & 75 & $\mathbf{3 2 , 6}$ & 65 & $\mathbf{2 8 , 3}$ & 55 & $\mathbf{2 3 , 9}$ \\
Yönlendirici $(\bar{x}=3,78)$ & 9 & 3,9 & 17 & 7,4 & 58 & 25,2 & 76 & $\mathbf{3 3 , 0}$ & 70 & $\mathbf{3 0 , 4}$ \\
Propaganda $(\bar{x}=3,78)$ & 9 & 3,9 & 19 & 8,3 & 63 & 27,4 & 60 & $\mathbf{2 6 , 1}$ & 79 & $\mathbf{3 4 , 3}$ \\
Hiciv/alaycı $(\bar{x}=3,47)$ & 9 & 3,9 & 32 & 13,9 & 81 & $\mathbf{3 5 , 2}$ & 56 & 24,3 & 52 & 22,6 \\
Mizah $(\bar{x}=3,46)$ & 11 & 4,8 & 31 & 13,5 & 75 & $\mathbf{3 2 , 6}$ & 66 & 28,7 & 47 & 20,4 \\
Reklam kokan $(\bar{x}=3,60)$ & 9 & 3,9 & 25 & 10,9 & 73 & $\mathbf{3 1 , 7}$ & 63 & $\mathbf{2 7 , 4}$ & 60 & 26,1 \\
Diğer & - & - & - & - & 2 & 0,9 & 1 & 0,4 & - & - \\
\hline
\end{tabular}

Katılımcılarda habere inanmayı ya da güven duymayı etkileyen ilk özelliklerin başında, kişi, kurum, muhabir ve site vb. gibi haberin kaynağ 1 gelmektedir $(\bar{x}=4,02)$. Ardından haberin gündemde oluşu $(\bar{x}=3,70)$, haber içeriğinin görsellerle desteklenmesi gibi içerik zenginliği $(\bar{x}=3,69)$, kişisel ilgi alanına yakınlığın $(\bar{x}=3,56)$ etkili olduğu görülmektedir. Diğer taraftan, etkileşim (yorum) ve beğeni sayılarının etki boyutunun daha geri planda kaldığı ortaya çıkmaktadır (bkz. Tablo 12). Katılımcılar için haber, güvenilir bir haber kaynağına sahipse, içeriği zengin, gündemde ve okunurluğu fazla ise inanırlığı yüksektir.

Tablo 12

Haberin doğruluğuna inanmayı etkileyen unsurlar

\begin{tabular}{lcrrrrrrrrr}
\hline & \multicolumn{2}{l}{ Hiç yok } & \multicolumn{2}{c}{ Çok az } & \multicolumn{2}{c}{ Orta } & \multicolumn{2}{c}{ Çok } & \multicolumn{2}{c}{ Çok fazla } \\
\hline $\mathrm{n}=230$ & $\mathrm{n}$ & $\%$ & $\mathrm{n}$ & $\%$ & $\mathrm{n}$ & $\%$ & $\mathrm{n}$ & $\%$ & $\mathrm{n}$ & $\%$ \\
\hline Haber kaynağı $(\bar{x}=4,02)$ & 6 & 2,6 & 9 & 3,9 & 50 & 21,7 & 73 & 31,7 & 92 & 40,0 \\
İçerik zenginliği $(\bar{x}=3,69)$ & 7 & 3,0 & 19 & 8,3 & 63 & 27,4 & 89 & 38,7 & 52 & 22,6 \\
Gündemde oluşu $(\bar{x}=3,70)$ & 11 & 4,8 & 22 & 9,6 & 49 & 21,3 & 89 & 38,7 & 59 & 25,7 \\
İlgi alanı $(\bar{x}=3,56)$ & 17 & 7,4 & 21 & 9,1 & 59 & 25,7 & 80 & $\mathbf{3 4 , 8}$ & 53 & $\mathbf{2 3 , 0}$ \\
Etkileşim $(\bar{x}=3,13)$ & 21 & 9,1 & 46 & 20,0 & 81 & 35,2 & 46 & 20,0 & 36 & 15,7 \\
Beğeni sayısı $(\bar{x}=3,04)$ & 27 & 11,7 & 41 & 17,8 & 85 & 37,0 & 48 & 20,9 & 29 & 12,6 \\
Paylaşım sayısı $(\bar{x}=3,24)$ & 19 & 8,3 & 42 & 18,3 & 71 & 30,9 & 60 & 26,1 & 38 & 16,5 \\
Reklam alması $(\bar{x}=3,37)$ & 37 & 16,1 & 51 & 22,2 & 57 & 24,8 & 53 & 23,0 & 32 & 13,9 \\
Okunma sayısı $(\bar{x}=3,34)$ & 13 & 5,7 & 33 & 14,3 & 72 & 31,3 & 78 & 33,9 & 34 & 14,8 \\
Arama motoru $(\bar{x}=3,36)$ & 18 & 7,8 & 35 & 15,2 & 69 & 30,0 & 62 & 27,0 & 46 & 20,0 \\
İdeolojik yakınlık $(\bar{x}=3,38)$ & 18 & 7,8 & 30 & 13,0 & 64 & 27,8 & 82 & 35,7 & 36 & 15,7 \\
\hline
\end{tabular}

Katılımcıların \%20'sinin haberlerin doğruluk kontrolünü hiç yapmadığı görülmektedir. Sosyal medya gibi hızlı yayılım özelliklerinin büyük işlev gördüğü bir mecrada hiçbir zaman doğruluk kontrolü yapmayan az da olsa bir kitlenin oluşu yalan haberlerin etkisini ve işleyişini hızlandıracaktır. Çoğu zaman doğruluk kontrolü yapanlar \%21,3 ve her zaman teyit eden katılımcı sayısı ise \%3,9 oluşu yaklaşık dörtte bir çoğunluğa karşılık gelse de bu durum sosyal 
medya gibi bir mecra söz konusu olduğunda izleyicinin eleştirel okuma yeterliliği yüksek olması beklentisine ters düşmektedir (bkz. Tablo 13).

Tablo 13

Doğruluk kontrolü ĕgilimi

\begin{tabular}{lrr}
\hline & $\mathrm{n}$ & $\%$ \\
\hline Hiçbir zaman & 46 & 20,0 \\
Nadiren & 53 & 23,0 \\
Bazen & 73 & 31,7 \\
Çoğu zaman & 49 & 21,3 \\
Her zaman & 9 & 3,9 \\
Toplam & 387 & 100.0 \\
\hline$(\bar{x}=3,66)(S=1,13)$ & &
\end{tabular}

Katılımcıların haberin doğruluk kontrolü yapıp yapmama kararı alma süreçlerinde ilk sırayı alan iki etken; var olan teyit kaynaklarını yetersiz bulmaları $(\bar{x}=3,34)$ ve aynı haberi alternatif kaynaklardan okuyarak teyit etmeyi yeterli bulmalarıdır $(\bar{x}=3,30)$. Bu durum haber teyidinde, katılımcıların kendilerine olan özgüvenin belirleyici rolünü ortaya koymaktadır. Katılımcıların güncel teyit kaynaklarına güvenmemeleri $(\bar{x}=3,20)$ ve okudukları haberin doğruluğundan şüphe duymamaları $(\bar{x}=3,06)$ yine bu özgüveni destekler niteliktedir. Haber konusuna ilgi duymamaları da $(\bar{x}=3,06)$ doğruluk kontrolünde etkilidir. Haberi nasıl teyit edeceklerini bilmemeleri $(\bar{x}=2,88)$, haberi teyide ayıracak zaman bulamamalar $(\bar{x}=2,81)$ ve teyide gerek görmemeleri $(\bar{x}=2,77)$ doğruluk kontrolü karar süreçlerinde daha az etkili olduğu görülmektedir (bkz. Tablo 14).

Tablo 14

Doğruluk kontrolü karar süreçleri etkenleri

\begin{tabular}{|c|c|c|c|c|c|c|c|c|c|c|}
\hline \multirow[b]{2}{*}{$\mathrm{n}=230$} & \multicolumn{2}{|c|}{ Hiç } & \multicolumn{2}{|c|}{ Çok az } & \multicolumn{2}{|c|}{ Orta } & \multicolumn{2}{|c|}{ Çok } & \multicolumn{2}{|c|}{ Çok fazla } \\
\hline & $\mathrm{n}$ & $\%$ & $\mathrm{n}$ & $\%$ & $\mathrm{n}$ & $\%$ & $\mathrm{n}$ & $\%$ & $\mathrm{n}$ & $\%$ \\
\hline $\begin{array}{l}\text { Haberin doğruluğundan şüphe duymamak } \\
(\bar{x}=3,06)\end{array}$ & 27 & 11,7 & 55 & 23,9 & 61 & 26,5 & 49 & 21,3 & 38 & 16,5 \\
\hline Nasıl teyit edeceğini bilmemek $(\bar{x}=2,91)$ & 42 & 18,3 & 42 & 18,3 & 67 & 29,1 & 52 & 22,6 & 27 & 11,7 \\
\hline $\begin{array}{l}\text { Güncel teyit kaynaklarına güvenmemek }(\bar{x} \\
=3,20)\end{array}$ & 23 & 10,0 & 40 & 17,4 & 65 & 28,3 & 71 & 30,9 & 31 & 13,5 \\
\hline $\begin{array}{l}\text { Var olan teyit kaynaklarını yetersiz } \\
\text { bulmak }(\bar{x}=3,34)\end{array}$ & 14 & 6,1 & 37 & 16,1 & 69 & 30,0 & 75 & 32,6 & 35 & 15,2 \\
\hline $\begin{array}{l}\text { Aynı haberi alternatif kaynaklardan } \\
\text { okuyarak teyidi yeterli bulmak }(\bar{x}=3,30)\end{array}$ & 19 & 8,3 & 37 & 16,1 & 70 & 30,4 & 63 & 27,4 & 41 & 17,8 \\
\hline Haber konusuna ilgi duymamak $(\bar{x}=3,06)$ & 32 & 13,9 & 39 & 17,0 & 66 & 28,7 & 67 & 29,1 & 26 & 11,3 \\
\hline $\begin{array}{l}\text { Teyit için yeterli zamanı bulamamak } \\
(\bar{x}=2,77)\end{array}$ & 43 & 18,7 & 55 & 23,9 & 65 & 28,3 & 45 & 19,6 & 22 & 9,6 \\
\hline $\begin{array}{l}\text { Teyide gerek olmadığını düşünmek } \\
(\bar{x}=2,77)\end{array}$ & 50 & 21,7 & 50 & 21,7 & 61 & 26,5 & 40 & 17,4 & 29 & 12,6 \\
\hline Diğer & - & & 1 & 0,4 & - & - & 1 & 0,4 & - & \\
\hline
\end{tabular}


Katılımcıların değerlendirmelerine göre yalan haberler büyük oranda medyaya güveni azaltmaktadır $(\bar{x}=3,86)$. Yalan haberlerin doğruluk kontrolü davranışını körüklediği gerçeği azımsanamayacak boyuttadır $(\bar{x}=3,58)$. Bunlara karşılık yalan haberler bahsettikleri konularla ilgili olarak izleyicisinde kaygıyı tetikleyebilmektedir $(\bar{x}=3,56)$. Yalan haberlerin haber okuma tutumlarını etkilemediği konusunda da katılımcılar yaklaşık oranlarda etkilenmekte, kararsız kalmakta ya da etkilenmemektedir $(\bar{x}=2,99)$ (bkz. Tablo 15). Ancak yalan haberin kat1lımciların büyük oranda (katılımcıların yaklaşık \%70'i) medyaya güvenini azaltması, aslında tutumların etkilendiğini ortaya koymaktadır.

Tablo 15

Yalan haberin tutum ve davranışlara etkisi

\begin{tabular}{|c|c|c|c|c|c|c|c|c|c|c|}
\hline \multirow[b]{2}{*}{$\mathrm{n}=230$} & \multicolumn{2}{|c|}{$\begin{array}{c}\text { Kesinlikle } \\
\text { Katılmiyorum }\end{array}$} & \multicolumn{2}{|c|}{ Katılmiyorum } & \multicolumn{2}{|c|}{ Kararsızım } & \multicolumn{2}{|c|}{ Katıliyorum } & \multicolumn{2}{|c|}{$\begin{array}{l}\text { Kesinlikle } \\
\text { Katılıyorum }\end{array}$} \\
\hline & $\mathrm{n}$ & $\%$ & $\mathrm{n}$ & $\%$ & $\mathrm{n}$ & $\%$ & $\mathrm{n}$ & $\%$ & $\mathrm{n}$ & $\%$ \\
\hline $\begin{array}{l}\text { Medyaya güvenimi azaltır } \\
(\bar{x}=3,86)\end{array}$ & 17 & 7,4 & 5 & 2,2 & 56 & 24,3 & 65 & 28,3 & 87 & 37,8 \\
\hline $\begin{array}{l}\text { Haber konusuyla ilgili kaygı } \\
\text { duymama neden olur }(\bar{x}=3,56)\end{array}$ & 20 & 8,7 & 17 & 7,4 & 67 & 29,1 & 66 & 28,7 & 60 & 26,1 \\
\hline Haber teyidine iter $(\bar{x}=3,58)$ & 20 & 8,7 & 16 & 7,0 & 66 & 28,7 & 65 & 28,3 & 63 & 27,4 \\
\hline $\begin{array}{l}\text { Haber okuma tutumumu } \\
\text { etkilemez }(\bar{x}=2,99)\end{array}$ & 39 & 17,0 & 45 & 19,6 & 62 & 27,0 & 47 & 20,4 & 37 & 16,1 \\
\hline Diğer & - & - & 1 & 0,3 & 3 & 0,8 & 3 & 0,8 & 20 & 5,2 \\
\hline
\end{tabular}

\section{Sonuç}

İçinde yaşadığımız toplumsal gerçekliği anlamlandırmak karşılaştı̆̆ımız bilgi ve haberlerle ilişkilidir. Sosyal medya ortamlarının hızı, yaygınlığı bireyin analizini, anlamlandırmasını, anlamlandırma hızını ve değerlendirmelerini kısıtlayabilmektedir. Haberi ya da bilgiyi çıkarları yönünde kullananların ya da ticari kar kaygısıyla hareket edenlerin aldatmalarına hizmet edebilir. İktidar güçlerinin düşüncelerinin kamuda yayılması ve benimsenmesinde yani bir uylaşımın sağlanmasında sosyal medya önemli bir kanaldır. Sosyal medyada çok hızlı ve algoritmalar sayesinde nokta atışı olarak yayılabilecek, okuyuculara dayatılabilecek olan yalan haberlerin ve bilgilerin olumlu ya da olumsuz etkileri, doğruluk kontrolü ve bu yöndeki tutumların geliştirilmesiyle mümkün olacaktır.

Basılı yayımların önem taşıdığı dönemlerden dijital içeriklerin yaygınlık kazandığ günümüze kadar iletişim ekolojisinde daima varlığını sürdüren yalan haberler, her dönemde okurun/izleyicinin ya da kullanıcının maruz kaldığı bir içerik türü olmuştur. Dijitalleşmenin etkisi haberin/bilginin üretimi, dağıtımı ve yaygınlaştırılması kolaylaşmış, sayısal olarak artmış, buna bağlı olarak haber doğruluğu çevrimiçi etkenler boyutunda belirsizleşmiştir. Küçük bir örneklem perspektifinde gerçekleştirilen bu çalışmada üç üniversite öğrencilerinin haber ve bilgi yayılımındaki davranış örüntüleri, katılımcı genç izleyici kitlesinin yalan haber odağında karar süreçleri, maruz kaldıkları haber ve bilgilerin etki boyutu, tutum ve davranışları değerlendirilmektedir.

Üç üniversitenin öğrencileri örnekleminde yapılan analizlerin sonucunda haber gereksiniminin çoğunlukla sosyal medyadan karşıladığı görülmektedir. Bu gereksinimi 
karşılamada ilk sırada Instagram yer alırken, ardından YouTube, Facebook ve Twitter onu izlemektedir. Yazılı ve görsel içerikli haberler ve bilgiler (yazı, fotoğraf, video) yalan haber odağında değerlendirildiğinde, fotoğraflı ve video gibi görsel nitelikli içeriklerin, (sadece) yazılı metne göre daha çok doğru kabul gördüğü ortaya çıkmıştır. Bu durumda araştırılan kitle üzerinde görselliğin, yalan habere katalizör oluşturabildiği ortaya çıkmaktadır.

Araştırmadaki genç haber okurları örnekleminde, magazin, siyaset ve ekonomi konulu yalan haberlerle daha sık karşılaştıkları, maruz kaldıkları bu haberlerin çoğunlukla propaganda ve yönlendirici (manipülatif) özellikte olduğu, reklam amaçlı yalan haberlerin bu özellikleri izlediği tespit edilmiştir. Kasıtlı amaç içeren, kışkırtıcı ve alaycılık yalan haber özellikleri içinde çok da az olmayan boyutlarda karşılaşılmaktadır. Eğlenceli/mizah türü içeriklerin daha inanılır bulunması risk oluşturmaktadır. Mizahî ya da eğlendirici içeriklerden şüphe duyulmaması, yalan habere mizahın bir katalizör oluşturabileceği ortaya çıkmaktadır.

Kişi, kurum, muhabir, site gibi haberin kaynakları, örneklemdeki okurların güven duygusunu etkilemekte ilk sırada gelmektedir. Haberin gündemde oluşu, içeriğinin zenginliği, kişinin ilgi alanında oluşu habere güveni etkilemektedir. Öte yandan etkileşim (yorumlar), paylaşım ve beğeni sayılarının etkisi bulgularda biraz daha geri planda değerlendirilse de etkisi sürmektedir.

Araştırma sonucunda haberin doğruluk kontrolüne hiç niyetlenmemiş bir azınlık olduğu görülmüştür. Sayıca az olsa bile bu durum sosyal medyanın hızı özelliği ile ilişkili olarak yalan haberin yayılımında önemli bir rol oynayacaktır. Katılımcı gençler doğruluk kontrolü konusunda yüksek özgüvene sahiptir ve doğrulatma yöntemi olarak çoğunluk bir haberi birçok alternatif kaynaktan okuyarak gerçekleştirmektedir. Ayrıca haber teyit kaynaklarını yetersiz bulmaları ve haberin doğruluğundan şüphe duymamaları da doğruluk kontrolü eğilimlerini sınırlamaktadır. Bu noktada, hemen olmasa da doğruluk kontrolü davranışının gelişmesinin yalan haberlerin artışıla paralellik göstereceğini belirtmek yerinde olur. Doğruluk kontrolü konusunda sosyal medya kullanıcısının bilinçlendirilmesine gereksinim olduğu bu küçük örneklem kitlesinde gerçekleştirilen araştırmanın bir sonucudur. Ayrıca aynı kitlenin sosyal medyada maruz kaldıkları yalan haberlerden dolayı medyaya duydukları güvenin azalması bu araştırmanın bir başka sonucudur. Hatta ilgilendikleri haber konusu kaygılarını arttırabilmektedir.

Küçük bir örneklemden elde edilen bu sonuçlar, haber ve gazetecilik konusunda özellikle de sosyal medyanın ağırlık kazandığı son zamanlarda haber ve bilginin zararlı etkilerini bertaraf etmede etkili ve yeni çalışmalara rehber olacaktır. 


\section{Kaynakça}

Adamic, L. A., ve Glance, N. (2005). The political blogosphere and the 2004 U.S. Election. LinkKDD '05: Proceedings of the 3rd international workshop on link discovery, 36-43. doi: doi.org/10.1145/1134271.1134277

Akaş, C. (1998). Bireysel hak, toplumsal görev ve kaçınılmaz durum olarak yalan. Cogito Dergisi, 16, 230-235.

Allcott, H. ve Gentzkow, M. (2017). Social media and fake news in the 2016 Election. Journal of Economic Perspectives, 31(2), s. 211-236.

Auberry, K. (2018). Increasing students' ability to identify fake news through information literacy education and content management systems. The Reference Librarian, 59(4), 179-187. doi: $10.1080 / 02763877.2018 .1489935$

Barthel, M., Mitchell, A. ve Holcomb, J. (2016). Many Americans believe fake news is sowing confusion. Pew Research Center. Erişim adresi: https://www.journalism.org/2016/12/15/manyamericans-believe-fake-news-is-sowing-confusion/

Bennett, W. L. ve Livingston, S. (2018). The disinformation order: Disruptive communication and the decline of democratic institutions. European Journal of Communication, 33(2), s. 122-139. doi: $10.1177 / 0267323118760317$

Cohen J. (1988) The analysis of variance. In Statistical Power Analysis for the Behavioral Sciences (Sec. ed.). Lawrence Erlbaum Associates.

Craft, S., Ashley, S. ve Maksi, A. (2016). Elements of news literacy: A focus group study of how teenagers define news and why they consume it. Electronic News, 10(3), 143-160. doi:10.1177/1931243116656716

Davey, L. (1990) "The Application of Case Study Evaluations". Practical Assessment, Research, and Evaluation, 2, s. 1-2. DOI: https://doi.org/10.7275/02g8-bb9

Derakhshan, H. ve Wardle, C. (2017). Understanding and addressing the disinformation ecosystem. Erişim adresi: https://pdfs.semanticscholar.org/9d91/58807cbf03fff609e74ef9e0e61c2e6088d8.pdf\#page=8

Erlanger, S. (2017). 'Fake news,' Trump's obsession, is now a cudgel for strongmen. The New York Times. Erişim adresi: https://www.nytimes.com/2017/12/12/world/europe/trump-fake-newsdictators.html

Fabry, M. (2017). Here's how the first fact-checkers were able to do their jobs before the internet. TIME. Erişim adresi: https://time.com/4858683/fact-checking-history/

Figueira, A. ve Oliveira, L. (2017). The current state of fake news: challenges and opportunities. Procedia Computer Science, 121, 817-825. doi:10.1016/j.procs.2017.11.106

Glasser, S. (2016). Covering politics in a "post-truth" America. BROOKINGS. Erişim adresi: https://www.brookings.edu/essay/covering-politics-in-a-post-truth-america/

Graves, L. (2016). Deciding What's True: The rise of political fact-checking in American journalism. New York: Columbia University Press. 
Hermida, A. (2010). Twittering the news. Journalism Practice, 4(3), s. 297-308. doi:10.1080/17512781003640703

Hermida, A. (2011). "Fluid spaces, fluid journalism: The Role of the 'active recipient' in Participatory Journalism." In Participatory Journalism: Guarding Open Gates at Online Newspapers. Edited by Jane Singer, Alfred Hermida, David Domingo, Ari Heinonen, Steve Paulussen, Thorsten Quandt, Zvi Reich, and Marina Vujnovic, (p.177-191). Malden, MA: John Wiley \& Sons.

Hodges, A. (2018). How "Fake News" Lost Its Meaning. Bepress: Erişim adresi: https://works.bepress.com/adamhodges/89/

İnceoğlu, Y. ve Çoban, S. (2016). Şimdi haberler. İnceoğlu, Y. ve Çoban, S. (Ed.) Haber okumalar içinde (s. 17-64). İstanbul: İletişim Yayınları.

Ingram, M. (2018). Most Americans say they have lost trust in the media. Columbia Journalism Review. Erişim adresi: https://www.cjr.org/the_media_today/trust-in-media-down.php

Iyengar, S. ve Hahn, K. S. (2009). Red media, blue media: Evidence of ideological selectivity in media use. Journal of Communication, 59(1), s. 19-39. doi:10.1111/j.1460-2466.2008.01402.x

Jang, S. M. ve Kim, J. K. (2018). Third person effects of fake news: Fake news regulation and media literacy interventions. Computers in Human Behavior, 80, 295-302. doi:10.1016/j.chb.2017.11.034

Jewitt, R. (2009). The trouble with twittering: integrating social media into mainstream news. International Journal of Media and Cultural Politics, 5(3), s. 231-238. doi:10.1386/macp.5.3.233_3.

Kalsın, B. (2018). Yeni medya sözlüğ̈̈ terimler ve kavramlar. Ankara: Gece Akademi.

Kiernan, L. (2017). 'Frondeurs' and fake news: how misinformation ruled in 17th-century France. The Conversation. Erişim adresi: https://theconversation.com/frondeurs-and-fake-news-howmisinformation-ruled-in-17th-century-france-81196

Kiesling, L. (2015). Harlan Coben: 'Every successful author still has to treat it as a job'. The Guardian. Erişim adresi: https://www.theguardian.com/books/2015/mar/24/harlan-coben-every-successfulauthor-still-has-to-treat-it-as-a-job

Kocabay, Ş. N. (2018). Doğruluk kontrol merkezi ve "yalan haber" kavramlarına ilişkin içeriklerin medyada yansımasının araștırılması. Akdeniz Üniversitesi Iletişsim Fakültesi Dergisi (AKILL), (29. Özel Sayıs1), 355-373.

Mansky, J. (2018). The Age-Old Problem of "Fake News". Smithsonian Magazine. Erişim adresi: https://www.smithsonianmag.com/history/age-old-problem-fake-news-180968945/

Mena, P. (2019). Cleaning up social media: The effect of warning labels on likelihood of sharing false news on Facebook. Policy and Internet. doi: https://doi.org/10.1002/poi3.214

Mitchell, A. (2018). Americans still prefer watching to reading the news - and mostly still through television. Pew Research Center. Erişim adresi: https://www.journalism.org/2018/12/03/americans-still-prefer-watching-to-reading-the-newsand-mostly-still-through-television/ 
Newman, N., Fletcher, R., Schulz, A., And1, S. ve Nielsen, K. (2019). Reuters Institute Digital News Report 2020. Digital News Report. Erişim adresi: https://reutersinstitute.politics.ox.ac.uk/sites/default/files/2020-06/DNR_2020_FINAL.pdf

Pariser, E. (2011). The filter bubble: What the internet is hiding from you. New York: Penguin Press.

Pepp, J., Michaelson, E. ve Sterken, R. K. (2019). What's new about fake news. Journal of Ethics and Social Philosophy, 16(2), s. 67-94. doi:10.26556/jesp.v16i2.629

Prior, M. (2007). Post-broadcast democracy how media choice increases inequality in political involvement and polarizes elections. New York: Cambridge University Press.

Reuters. (2017). What can publishers do about "fake" news? Reuters. Erişim adresi: https://www.reuterscommunity.com/topics/establish-your-identity/what-can-publishers-doabout-fake-news/

Rigel, N. ve Çağlar, Ş. (2010). Kanatlı kelimeler örneklerle haber tasarımı. İstanbul: Anonim Yayincilik.

Schiffrin, A. (2014). Global muckraking: 100 years of investigative journalism from around the world. New York: New Press.

Schlapp, H. (2002). Gazeteciliğe giriş/ Mesleğe yönelik ders kitabı. (I. Aygün, Çev.). Konrad Adenauer Stiftung Medya Uygulamaları Üzerine Çalışmalar. İstanbul: Vestfalya Eyaletler Yayımevi.

Schneider, W. ve Raue, P. (2002). Gazetecinin el kitabı/ Mesleğe yönelik ders kitabı. (I. Aygün, Çev.). Konrad Adenauer Stiftung Medya Uygulamaları Üzerine Çalışmalar. Ankara: Dilek Ofset.

Silvestre, D. (2018). How to escape information overload. Medium. Erişim adresi: https://medium.com/swlh/how-to-escape-information-overload-ab36075ee6bd

Tabachnick, B.G. ve Fidell, L.S. (2013). Using Multivariate Statistics, (6. ed.). Boston: Pearson.

Taiwo, R. (2014). Impoliteness in online forums: A study of trolling in Nairaland. Chiluwa, P. Ifukor, R. Taiwo (Ed.), Pragmatics of Nigerian English in Digital Discourse içinde (s. 67-76). Lincom Europa.

Tandoc, E. C. ve Vos, T. P. (2015). The Journalists is marketing the news social media in the gatekeeping process. Journalism Practice, 10:8, s. 950-966. doi:10.1080/17512786.2015.1087811

Tandoc, E. C., Jenkins, J. ve Craft, S. (2018). Fake news as a critical incident in journalism. Journalism Practice, 13(6), s. 673-689. doi:10.1080/17512786.2018.1562958

Taş, O. ve Taş, T. (2018, Aralık). Post-hakikat çağında sosyal medyada yalan haber ve Suriyeli mülteciler sorunu. Galatasaray Üniversitesi İletişim Dergisi (29), s. 183-208.

Tavşanc1l, E. (2002). Tutumların ölçülmesi ve SPSS ile veri analizi. Ankara: Nobel Akademik Yayincilik.

TSE. (2006). Bilişim terimleri sözlüğü. Bilişim Sözlüğü-TSE. Erişim adresi: https://statik.tse.org.tr/upload/tr/dosya/icerikyonetimi/552/19012016170409-4.pdf

Uluk, M. (2018). Hakikat sonrası çağda yeni medya ve yalan haber. Eskişehir : Dorlion Yayınları.

Waisbord, S. (2018). Truth is what happens to news on journalism, fake news, and post-truth. Journalism Studies, 19:13, s. 1866-1878. doi:10.1080/1461670X.2018.1492881 
Wang, A. B. (2016). 'Post-truth' named 2016 word of the year by Oxford dictionaries. The Washington Post. Erişim adresi: https://www.washingtonpost.com/news/the-fix/wp/2016/11/16/post-truthnamed-2016-word-of-the-year-by-oxford-dictionaries/

Wardle, C. (2017). Fake news. It's complicated. FirstDraft. Erişim adresi: https://medium.com/1st$\mathrm{draft/fake-news-its-complicated-d0f773766c79.}$

Yazıcıŏglu, Y. ve Erdoğan, S. (2004). SPSS uygulamalı bilimsel araştırma yöntemleri. Ankara: Detay Yayıncilik.

Yıldırım, A. ve Şimşek, H. (2005). Sosyal bilimlerde nitel araştırma yöntemleri. Ankara: Seçkin Yayincilik.

\section{Summary}

It is essential to present the news, which is an element of communication, objectively, correctly, understandably and truthfully. However, an edited media output may not be independent from the influence of individual, ideological and institutional structures in the production process. A reality that can attract the attention of the society and improve its knowledge can be reconstructed in accordance with the structure, technology and ideology of the media organization to be published. Communication practices that change and transform with the effect of digitalization enable news production to take place in a more flexible structure. User interaction and participation, etc. New media environments that offer possibilities have structural features that allow fast, instant and mobile communication. New media environments that offer active participation opportunities to the user have structural features that allow fast, instant and mobile communication. As a result, these media environments, which enable users to produce, share and share different types of content (text, video, audio and visual), have also led journalism practices to change and transform. While these developments provided opportunities such as instant, easy and free access to the news, it also brought the possibility of erosion of the news in terms of quality. The support of the spread of unverified or inaccurate information, especially in social media, accelerated the insecurity of news.

The concept of fake news emerges as a result of the publication of the news texts by being edited in a false or misleading way. They may appear as information collected under journalism principles; they cover information pollution, false or misleading content. Fake news producers can use this news to discredit someone, to honor those they are party to, or to disseminate certain ideas. Due to the fact that they can be shocking or unusual on the one hand, they can spread as quickly as viruses, and on the other hand, they can turn into advertising income of content producers due to clicks, views and likes within the current technological access practices. In particular, the technological and economic-political structure of the new media is clearly effective at this point. Lack of legal regulations and difficulties in enforcement, supporting the easy manipulation and provocation of the masses are among the major disadvantages of social media. Users have the opportunity to send information, photos, videos and narratives about the news events that they witness firsthand through their social media accounts. The malicious use of private and corporate accounts, which had the opportunity to spread the fake information and content quickly, caused their social networks to have a negative reputation for hosting fake news. 
The news or information process that develops without discipline can naturally cause different effects, chaos and confusion. Therefore, the manipulative effect of fake news or information and the evaluation of the impact processes are of great importance.

Although accuracy control of news texts has a long history, it limits the collective struggle with fake news due to the speed of distribution and access volume of content / news circulating in social networks. Current communication technologies have facilitated content production and dissemination, on the other hand enabled the fact-checking platforms of the content to enter our lives. Users can make their own decisions about the content they suspect, and they can affect the spread of these contents by revealing the content they do not find correct with the help of the complaint mechanism. Social media users play an active role in the spread of fake news, by sharing unconsciously misleading and fabricated content, being affected by disinformation campaigns, through networks that cover their family and friends, as well as news sites. Therefore, awareness of individuals about news or information fact-checking and ability to develop measures should be considered important and encouraged. On the other hand, more emphasis should be placed on developing news literacy or the ability to critically analyze and evaluate news content.

The purpose of this study is to explain the fake news evaluation of individuals who may be exposed to manipulations of potentially malicious actors within institutions and society, depending on the basis of the erosion of the news on the internet, and also and to provide ideas to assist decision-making about fake news in these settings. In this context, it evaluates the processes of decision and influence about false news, the attitudes and behaviors they develop and the mechanisms of dissemination of such news that individuals are exposed to on social media.

Quantitative research method was used in the research; is a descriptive, that is, a field study that reveals the current situation. Questionnaire is preferred as the data collection technique. The universe of the research is social media users and three university students. The student sample that can represent the student population in these universities was determined using the stratified sampling method, which is the probabilistic sampling method. Data were collected from a total of 230 students from three universities who were selected by simple random sampling as a result of proportioning that could represent the universe. The reason for choosing this sample is that university students who are more familiar with technology are representatives of the younger generation, spend more time on social media, and their education level is higher than others.

The research questionnaire consists of four basic categories, excluding questions measuring demographic information: media use, the process of encountering fake news (news elements, content and topics, features), decision-making process of believing / not believing the news, fact-checking.

The majority of students meet their news needs mostly from social media. It is seen that it uses Instagram, followed by Youtube, Facebook and Twitter social media platforms. Visual content is more accepted than (only) written text. In news about magazine, politics and economy, fake news is more common. The propaganda feature is more common in fake news. Afterwards, it was revealed that those who were guiding, provocative and involving intentional purpose followed him. It is determined that the news with fun content is more believable. The propaganda feature is more common in false news. Afterwards, it is determined that those who 
were manipulative, provocative and involving intentional purpose followed him. It is defined that the news with fun content is more believable. The sources of the news (person, institution, reporter, website etc.) come first in influencing the trust of the participating university audience. In the tendency to be fact-checking, reading the same news from alternative sources is the application that comes first. The fact that the news fact-checking sources are insufficient, and the individuals do not doubt the accuracy of the news also limits the approach to verifying the news. 